\title{
The Impact of Environmental Knowledge and Awareness on Sustainability Performance of Organizations: The Mediating Role of Employee Green Behaviour
}

\author{
Neruja, S., ${ }^{1} \&$ A. Anton Arulrajah ${ }^{2}$ \\ ${ }^{1}$ Bachelor of Business Administration (BBA), Department of Management, Faculty of Commerce and \\ Management, Eastern University, Sri Lanka \\ ${ }^{2}$ Senior Lecturer, Department of Management, Faculty of Commerce and Management, Eastern University, Sri \\ Lanka \\ Correspondence: A. Anton Arulrajah, Department of Management, Faculty of Commerce and Management, \\ Eastern University, Sri Lanka.
}

Received: June 15, 2021

Accepted: July 29, 2021

Online Published: August 9, 2021

doi:10.5539/ibr.v14n9p68

URL: https://doi.org/10.5539/ibr.v14n9p68

\begin{abstract}
This study examined the impact of environmental knowledge \& awareness of employees on sustainability performance of organization among 173 commercial bank employees in Batticaloa Region of Sri Lanka. It explored environmental knowledge \& awareness of employees associated with employee green behaviour and the possible mediating role of employee green behaviour between environmental knowledge \& awareness and sustainability performance of organization. Multiple regression analysis demonstrated that the environmental knowledge \& awareness of employees were significantly associated with green behaviour among the employees of surveyed banks. It was also established that the association of environmental knowledge \& awareness of employees and sustainability performance of the bank is partially mediated by employee green behaviour. This study contributes to fill out the research gaps exist in the area of study to some extent and offers practical implications for the managers of banks to establish efficient and constructive mechanisms and encourage the bank's staff to implement environmental policies into actions.
\end{abstract}

Keywords: environmental knowledge and awareness, employee green behaviour, sustainability performance

\section{Introduction}

Healthy natural environment is essence for healthy life. Healthy environment and healthy life are both sides of a same coin. If organizational activities disturb the natural environmental balance, which will definitely affect healthy life of people and their growth as well as survival. Hence, organizations need to focus on environmental protection and sustainability. In today's business environment, stakeholders are increasingly pressuring the organizations to display the commitment towards sustainability and organizations also compelled to extend the scope of their business performance over and above the economic terms. Further, they are forced to be transparent as to the way of dealing with social and environmental concerns. Business organizations have to display their environmental and social contributions in addition to their economic or financial performance.

According to World Business Council for Sustainable Development, sustainability is defined as "ensuring a better quality of life for everyone, for now and for generations to come" (Goel, 2010, p. 34). In an institutional point of view, corporate sustainability is described as fulfilling the requirements of primary and secondary stakeholder groups of a company without endangering its capacity to satisfy potential stakeholder's requirements (Turan et al., 2008).

While comparing with chemical, mining, health/drug, oil and textile sectors, even though banking industry is unlikely to have a detrimental influence, the number of banks in total is huge enough to have a major influence on the environment (Ozcelik \& Ozturk, 2014) and banks have been pointed out as the sector that is increasingly affecting, and is affected by, environmental issues (Kiernan, 2001; McKenzie \& Wolfe, 2004).

Nevertheless, banks are increasingly engaged in environmental protection and management initiatives along with socio-economic activities, to reduce adverse environmental impact by implementing green banking practices. 
Business practices to move towards sustainability, not only include green processes and products, but also consider employees as drivers of sustainable business (Ones \& Dilchert, 2012). Hence, to avoid negative environmental consequences, it is necessary to change the nature of employee's activity/action into a more sustainable ways of living.

While employees' environmental initiatives can play a key role in the success of corporate sustainability initiatives, previous researchers do not emphasize upon their importance, nature and scope (Boiral, Paille \& Raineri, 2015; Boiral, Talbot \& Paille, 2013). Further, there is still lack of studies on employee engagement in sustainable workplace and holistic approach for sustainability (Ruepert et al. 2016). This indicates there is a knowledge gap with regard to these issues.

Moreover, as mentioned by researchers (Norton, Parker, Zacher \& Ashkanasy, 2015; Opatha, 2019; Thevanes \& Arulrajah, 2020), despite the fact numerous research on employee green behavior have been undertaken, there is a need to gather additional empirical evidences to ensure the precision of the results. Thus, it is quite clear there is an empirical gap exists in the research topic.

Eventually, majority of the previous research on sustainability performance has been done among manufacturing organizations and logistic service providers in developed countries (Langwell \& Heaton, 2016; Burawat, 2019; Iqbal, Ahmad \& Ahmad, 2019; Korzeb \& Samaniego-Medina, 2019) and lack of research works have been conducted in service industries particularly in Sri Lankan banking sector context. This reveals that there is a population gap.

In order to contribute the young field of organizational sustainability performance and to fill the above-mentioned gaps to some extent, the present study tries to answer whether the association between environmental knowledge \& awareness of employees and organizational sustainability performance is mediated by employee green behaviour? Practical implications for the managers of banks to establish efficient and constructive mechanisms and encourage the bank's staff to implement environmental policies into actions can be provided by the results generated in the present study.

The rest of this paper is organized as follows: Section 2 of the paper provides a brief review of extent literature with respect to variables and the hypotheses of the research. Section 3 explains proposed conceptual framework of this study. Section 4 presents the methodology of the research. Section 5 reports the results and discussion. And the rest of the sections deal with implications, recommendations, limitations and directions for the future research.

\section{Literature Review}

\subsection{Environmental Knowledge and Awareness}

According to Davenport and Prusak (1998, p. 5), knowledge is defined as "a fluid mix of framed experience, values, contextual information, and expert insight that provides a framework for evaluating and incorporating new experiences and information". Furthermore, as stated by Bower (1990) an individual's capability to acknowledge and give close attention to an element's existence and its features is defined as awareness. Being conscious can be seen as a procedure resulting from a flow of knowledge and learning (Arboleda \& Alonso, 2014).

Environmental knowledge refers to a person's insight of environmental challenges and the way of solving the issues (Zsoka, Szerenyi, Szechy \& Kocsis, 2013). Environmental awareness on the other side, is concerned with people's understanding and behavioral attitudes towards environmental issues and values related to the environment (Arcury \& Johnson, 1987). Ziadat (2010, p. 136) consider that environmental awareness is the "levels of knowledge that different groups of people possess concerning the severity of environmental problems and how they respond to or interact with their environment".

Based on several studies conducted previously (Sinha, Kasar, Tiwari \& Sharma, 2008; Kwatra, Pandey \& Sharma, 2014), in certain contexts the terms environmental knowledge and awareness are interchangeable. Current study has also considered environmental knowledge and awareness as a single concept.

\subsection{Sustainability Performance}

A key challenge organization facing is the today's quickly evolving environment that needs organizations to design and implement management practices that capture rising Institutional Pressures for Sustainability (IPS) from various stakeholders, such as customers, vendors, regulators, nongovernmental organizations, and others (Baker \& Schaltegger, 2015). It is therefore necessary for businesses to be more responsible and to rethink their activities (Epstein, Yuthas \& Buhovac, 2010). 
World Commission on Environment and Development (WCED) (1987) expresses far more quoted definition of sustainability. WCED (1987) states sustainable development is linked to social, economic and environmental elements such as the resource boundaries (materials, energy, land and waste), intergenerational and intra generational equity, equitable access to scare resources and a progressive social and economic transformation. The term 'sustainability' was defined by Elkington (1994) as the expansion of the corporate perspective which takes environmental, social and economic aspects into consideration.

Meanwhile, Schaltegger and Wagner (2006) describe sustainability performance as the firm's performance across all dimensions and for all drivers of corporate sustainability. At present, by integrating green initiatives into their business practices a growing number of companies are pursuing sustainability goals (Teixeira, Jabbour, $\&$ de Sousa Jabbour, 2012).

\subsubsection{Triple Bottom Line (TBL) Theory}

Literature explains an organization's sustainable performance is, as enhancing its performance with regard to the commitment towards environmental and social concerns while achieving a financial benefit. Whereas the three components of sustainability have been explored individually, Elkington's (1998) triple bottom line approach highlighted the necessity to examine them all at the same time.

Elkington (1994), one of the world's leading experts with regard to sustainability and founder of Sustainability agency, in mid-1990s attempted to assess sustainability within a new model of assessing corporate American performance. This system was called as Triple Bottom Line (TBL), which was intended to go beyond the traditional profit, gain on investment, and shareholder value calculations to include social and environmental elements. TBL approaches the notion of sustainability in form three perspectives: economic, social and environmental.

"Economic dimension of TBL framework represents the impact of organization's operation application on economic system" (Alhaddi, 2015, p. 8). Social dimension of TBL framework represents the requirement to execute the applications which are beneficial and fair to labour, human capital and society. Environmental dimension of TBL framework is to direct next generations to use natural resources without affecting environmental sources. Thus, the extended corporate performance, often called sustainable corporate performance will include components of financial, environmental and social measures of performance. Therefore, it is critical to assess sustainability performance as a whole.

\subsection{Employee Green Behaviour}

Employee green behaviour is defined as the extent to which a particular employee takes actions in respect of greening (Opatha, 2019). Green behaviour includes green actions and activities of employees. According to Opatha (2015), every organization is in need of making all its employees green. EGB is defined as the actual behaviours of employees in the organizations which contribute to reduce the harmful effect or increase the constructive action on natural environment (Thevanes \& Arulrajah, 2016; Thevanes \& Arulrajah, 2020). Any observable behavior of individual which assists in achieving workplace environmental sustainability can be defined as EGB (Norton, Zacher \& Ashkanasy, 2015). Employee green behaviours which encompass all behaviours at individual level which tend to have a favourable impact on environmental sustainability, and such behaviours are at one's discretion, deliberate and under the control of employees entirely (Vinojini \& Arulrajah, 2017; Opatha, 2019; Thevanes \& Arulrajah, 2020; Opatha \& Kottawatta, 2020a; Opatha \& Kottawatta, 2020b; Malsha, Arulrajah, \& Senthilnathan, 2020; Weerakoon, Sellar, \& Arulrajah, 2021).

In achieving collective sustainable green performance, the efforts of employees, management, other internal stakeholders and even some inputs by external supply chain partners in multiple fields are needed for an organization. The need to encourage pro-environmental behaviour (PEB) in the workplace has lately been highlighted by the academics who are with an interest in corporate environmental sustainability (Paille, Boiral \& Chen, 2013).

The degree to which employees engage in environmental friendly actions and extend their responsibilities above job roles is sometimes referred to as the notion of proactive green behaviour (Bissing-Olson, Iyer, Fielding, \& Zacher, 2013). Ones and Dilchert (2012) argue that EGBs are an essential component of organizational environmental sustainability. Employees extend their work limitations to include social and environmental operations to successfully manage the environmental impacts of the organization (Valente, 2012).

\subsection{Environmental Knowledge \& Awareness and Sustainability Performance}

The sustainability process should be combination of inter-correlated elements of social, environmental and financial aspects and it should be established in the long run (Wang, Choi \& $\mathrm{Li}, 2008$ ). Success of environmental 
management systems relies mainly on the employee's awareness about environmental protection and their comprehension of their role and responsibilities within this process. "It is not an exaggeration to mention here that the employees are the key to success or failure of eco-activities of an organization" (Opatha \& Arulrajah, 2014 , p. 105). The significance of employees' environmental awareness, their involvement in environmental activities, and training and motivation for the environmental strategies to be successful is highlighted by Fernandez, Junquera and Ordiz (2003). Regular engagement of employees in meetings can help to distribute information within the organization, and employees learning new skills can improve the ability of the business to adapt to environmental changes (Walz \& Niehoff, 2000).

The organization should enable the workers to engage in environmental projects and provide them environmental training to improve their expertise, engagement, retention and work-related outcomes (Anu Singh \& Shikha, 2015). According to Teixeira, Jabbour and Jabbour, (2012), this will increase the organization's financial performance. Employees participating in environmental practices have the benefit of helping them develop new skills and thus improve job satisfaction. This will give new experiences outside the usual workplace for the employees and also provides opportunity to implement taught form from the offices at home while enhancing the social performance (George \& Jayakumar, 2017).

Although these environmental knowledge \& awareness of employees are directly related to the environmental performance dimension of sustainability performance, when employees have proper knowledge and awareness about the association between financial, environmental and social issues and understood well, they would engage in sustainability performance of organization. Holt and Barkemeyer (2012) stated that there is a presumed link between environmental education, public awareness of the environment and sustainable development. As per the theoretical considerations discussed above, environmental knowledge $\&$ awareness appears to have a positive association with sustainability performance of the organizations. Thus, the study formulates first hypothesis as follows:

\section{$H_{1}$ : There is a positive relationship between environmental knowledge \& awareness and sustainability performance.}

\subsection{Environmental Knowledge and Awareness and Employee Green Behaviour}

As per Narayanan and Boyce (2019) awareness over environmental issues has increased, and many individuals are willing to support companies that are developing and launching greener products to reduce their negative impact on environment.

Studies conducted previously on the subject have looked into various aspects, such as environmental knowledge that influence ecological behaviour of an individual. Kaplan (1991), for example, argued that one's decision-making is considerably influenced by the level of knowledge someone possess regarding an issue. It is demonstrated by other scholars (e.g., Mostafa, 2006; Vinojini \& Arulrajah, 2017) that information typically impacts pro-environmental attitudes, which in turn, induce ecologically responsible behaviour. Environmental awareness is defined by Kollmuss and Agyeman (2002, p. 253) as "knowing of the impact of human behaviour on the environment".

According to Palmberg et al. (2015), the students will become more concerned about the environment by developing ecological knowledge and awareness of environmental issues among them and therefore be motivated to engage in pro-environmental behaviour (Kim, Vaswani, Kang, Nam \& Lee, 2017). Based on the empirical evidence and discussion, second hypothesis of the study is developed as follows: $H_{2}$ : There is a positive relationship between environmental knowledge \& awareness and employee green
behaviour.

\subsection{Employee Green Behaviour and Sustainability Performance}

In the business community, proactive approach of environmental management has been continuously required by balancing environmental, economic, and social performance as a part of the obligation for the society (O’Donohue \& Torugsa, 2016).

Laszlo \& Zhexembayeva (2011) argued that changes in thinking and behaviour that spread among all levels of staffs in all sectors of a business is required for embedding Environmental Sustainability (ES) deeply into an organization. The effectiveness of environment management of an organization relies on the environmentally friendly behaviour of the employees as their actions increase the environmental performance of the company in the aggregate (Lo, Peters \& Kok, 2012). Better environmental performance is often claimed to lead to better economic performance (Wagner, 2013). Sustainable community development involves pro-environmental employee behaviours (PEBs) at work. If employees feel a company is following its professed values, it has a 
significant influence on engagement of employees, which in turn has a substantial influence on organizational and financial performance (Berrone \& Gomez-Mejia, 2009). In addition, green behaviour involvement can act as a stress buster. This will contribute to the firm's social performance (George \& Jayakumar, 2017). Consequently, employee green behaviour has a strong association with sustainability performance. As a result, the third hypothesis is proposed as follows:

$H_{3}$ : There is a positive relationship between employee green behaviour and sustainability performance.

2.7 Employee Green Behaviour Mediates the Relationship between Environmental Knowledge \& Awareness and Sustainability Performance

An organization needs employees who are sufficiently aware of sustainability, believe in sustainability seriously, who feel positively about sustainability, intend to behave positively and considerably towards sustainability, and are involved in sustainability. Indeed, without having green employees, the success of an environmental management and environmental strategy cannot be achieved. It was noticed by Anderrson and Bateman (2000) that the employees' voluntary activities contribute significantly to sustainability by exhibiting new ways for a company to reduce its negative environmental impact. Environmental behaviour of employee contributes to the greening of the organization (Robertson \& Barling, 2013). Roy, Boiral and Paillé (2013) insisted that the spontaneity of an eco-friendly behaviour by supplementing environmental management systems can enhance environmental performance. It has been confirmed by several authors, that financial performances are driven by outcomes of employees that are associated with environmental-oriented practices such as competence, involvement, and motivation (Jabbour_\& de Sousa Jabbour, 2016; Masri \& Jaaron, 2017). In fact, it may be helpful to promote a safe environment with exposures to nature by encouraging the use of open break areas (Largo-Wight, 2011). This can increase employee engagement. This could improve employees' mental health and their empowerment among society and may impact social performance. In relation to the preceding theoretical issues, it appears that with regard to employee green behavior as a mediator, sustainability performance is influenced by environmental knowledge \& awareness. Accordingly, this study proposes following fourth hypothesis:

$H_{4}$ : Employee green behaviour mediates the relationship between environmental knowledge \& awareness and sustainability performance.

\section{Conceptual Model}

Based on what has been said so far, the model depicted in Figure 1 is proposed to test in this study, for the purpose of examining the association between environmental knowledge \& awareness and sustainability performance of organizations while having employee green behavior as the mediator.

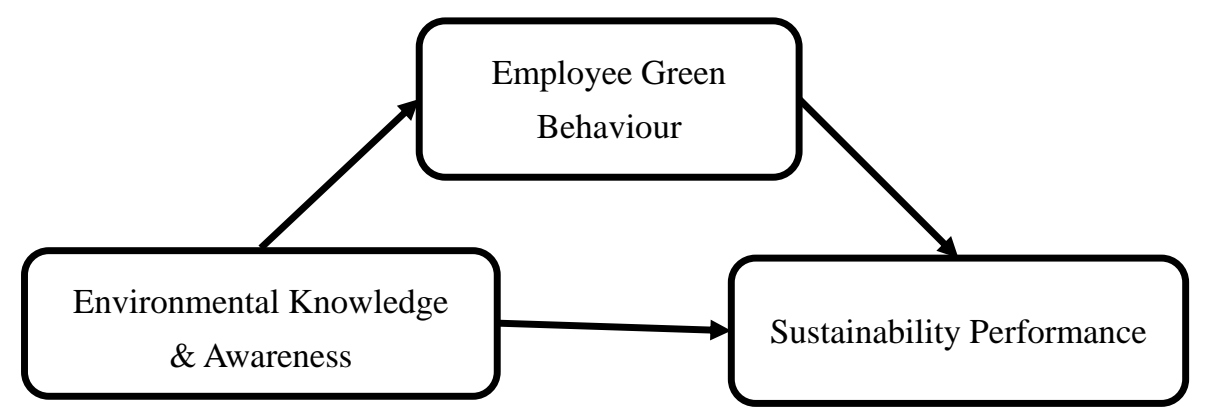

Figure 1. Conceptual Model

(Source: Safari, Salehzadeh, Panahi \& Abolghasemian, 2018; Iqbal, Hassan, Akhtar \& Khan, 2018)

\section{Methodology}

The objective of the study is to explore whether employee green behaviour mediates the relationship between environmental knowledge and awareness and sustainability performance in selected commercial banks. Current study's statistical population is comprised of all the employees of the five selected commercial banks in Manmunai North and Eravur Pattu Divisional Secretariat in Batticaloa District of Sri Lanka. Since, the population of this study consists of limited number of employees of selected banks; in order to validate and achieve the objectives of this study, total population study method was used where, the entire population that meet the criteria are included in the research being conducted and total population was selected for study purpose. 
Each single employee is considered as a respondent of this study.

Primary data was collected using close ended structured questionnaire. It is assured to the participants that their responses would be kept confidentially. Accordingly, questionnaires were given to all employees of selected banks in the study area, of which 173 respondents completed and returned back the valid questionnaires which were used for data analysis. Collected data were analyzed using SPSS version 22.0, where, bivariate Pearson correlation analysis was used to identify the relationships among the variables and the mediating effect was investigated by multi-step regression analysis of Barron and Kenny (1986).

\subsection{Measures}

Environmental knowledge \& awareness was assessed using a five items scale to assess bank employees' conception towards their level of environmental knowledge \& awareness. To measure the environmental knowledge \& awareness of bank employees, the question items were adapted from Gatersleben, Steg and Vlek, 2002. This study has used a Likert scale ranging from 1 to 5 where 1 indicates "strongly disagree" and 5 indicates "strongly agree", with the mean score indicating the variable. Cronbach's Alpha was 0.824 in this study.

Sustainability performance was assessed with a scale consisting of fifteen question items, which was created by Khan and Quaddus, (2015) and found to be reliable and valid in their study. This study has used a Likert scale ranging from 1 to 5 where 1 indicates "strongly disagree" and 5 indicates "strongly agree", with the mean score indicating the variable. Cronbach's Alpha was 0.901 in this study

Employee green behaviour was assessed using a scale consisting of five items that had previously been found to be valid and reliable in a previous study (Kaiser, Oerke \& Bogner, 2007; Robertson \& Barling, 2013; Kim, Kim, Han \& Holland, 2016). This study has used a five-point Likert scale with 1 for "strongly disagree" and 5 for "strongly agree" to measure green behaviour of bank employees and the Cronbach's Alpha was 0.783.

The reliability of the instrument is measured using Cronbach's Alpha Coefficient (CAC) analysis. As Cronbach's Alpha values for all the variables are above 0.7, all items which are considered in this study are to be reliable, which suggest that the internal reliability of instrument for satisfactory. Table 1 shows the results of reliability analysis of instrument which is used in this study.

Table 1. Reliability Analysis for Overall Variables

\begin{tabular}{|l|c|c|}
\hline \multicolumn{1}{|c|}{ Variables } & Number of question items & Cronbach's Alpha Value \\
\hline Environmental Knowledge \& Awareness & 5 & 0.824 \\
\hline Employee Green Behaviour & 5 & 0.783 \\
\hline Sustainability Performance & 15 & 0.901 \\
\hline
\end{tabular}

(Source: Survey Data)

\section{Results and Discussion}

\subsection{Descriptive Statistics and Correlation Analysis}

In order to achieve the objectives of the study bivariate and multivariate analysis have performed by using SPSS 22.0. Table 2 presents the descriptive statistics and correlations for all the variables tested in this study. The descriptive statistics of the study revealed that there were high levels of environmental knowledge $\&$ awareness, employee green behaviour and sustainability performance. The mean values fall between the ranges of 3.40 to 4.20. In addition, respondents have moderately common opinion as the standard deviations fall around 0.5 .

Correlation analysis is used to measure the relationships among the environmental knowledge $\&$ awareness, employee green behaviour and sustainability performance. Direction, strength and significant of the bivariate relationship between the variables are indicated by Pearson correlation coefficient. According to Gogtay \& Thatte (2017), the correlation coefficient values (r) ranging from 0.10 to 0.29 are considered weak, from 0.30 to 0.49 are considered medium and from 0.50 to 1.0 are considered strong. The results of the analysis show that there is a strong positive and significant relationship between environmental knowledge and awareness and sustainability performance, environmental knowledge and awareness and employee green behaviour and employee green behaviour and sustainability performance as the values of correlation coefficient falls under the range of \pm 0.5 to \pm 1.00 and the $p$-value is 0.000 . 
Table 2. Descriptive Statistics and Correlation Matrix

\begin{tabular}{|c|c|c|c|c|c|}
\hline \multicolumn{2}{|r|}{ Variable } & Mean & $\begin{array}{l}\text { Standard } \\
\text { Deviation }\end{array}$ & 1 & 2 \\
\hline 1 & $\begin{array}{lll}\text { Environmental } & \text { Knowledge } & \& \\
\text { Awareness } & & \end{array}$ & 4.03 & 0.65 & & \\
\hline 2 & Employee Green Behaviour & 3.81 & 0.60 & $0.582^{* *}$ & \\
\hline 3 & Sustainability Performance & 4.07 & 0.49 & $0.607^{* * *}$ & $0.686^{* *}$ \\
\hline
\end{tabular}

(Source: Survey Data)

\subsection{Mediation Analysis}

Further, this study has followed Baron and Kenny's (1986) four step meditational processes to analyze whether employee green behaviour plays a mediating role, in which several regression analyses are conducted and significance of the coefficients is examined at each step.

Table 3. Simple Mediation Analysis

\begin{tabular}{|c|c|c|c|c|c|c|c|}
\hline Step & Path & Independent Variable & Dependent Variable & $\mathbf{R}^{2}$ & $\mathbf{B}$ & Sig. & F-statistic \\
\hline 1 & $\mathrm{c}$ & $\begin{array}{lll}\text { Environmental Knowledge } \& \\
\text { Awareness }\end{array}$ & $\begin{array}{c}\text { Sustainability } \\
\text { Performance } \\
\end{array}$ & 0.368 & 0.461 & 0.000 & 99.548 \\
\hline 2 & a & $\begin{array}{l}\text { Environmental Knowledge and } \\
\text { Awareness }\end{array}$ & $\begin{array}{c}\text { Employee Green } \\
\text { Behaviour }\end{array}$ & 0.339 & 0.541 & 0.000 & 87.573 \\
\hline 3 & $\mathrm{~b}$ & Employee Green Behaviour & $\begin{array}{c}\text { Sustainability } \\
\text { Performance }\end{array}$ & 0.471 & 0.561 & 0.000 & 152.019 \\
\hline \multirow[t]{2}{*}{4} & \multirow[t]{2}{*}{$c^{\prime}$} & $\begin{array}{l}\text { Environmental Knowledge \& } \\
\text { Awareness }\end{array}$ & \multirow{2}{*}{$\begin{array}{l}\text { Sustainability } \\
\text { Performance }\end{array}$} & \multirow[t]{2}{*}{0.536} & 0.239 & 0.000 & \multirow[t]{2}{*}{98.045} \\
\hline & & Employee Green Behaviour & & & 0.412 & 0.000 & \\
\hline
\end{tabular}

Step 1 shows that $36.8 \%$ of the variation in sustainability performance is explained by environmental knowledge and awareness. Remaining $63.2 \%$ of variation is explained by other factors which are not taken into consideration and if environmental knowledge and awareness is increased by one unit sustainability performance will improve by 0.461 units. Thus, step one concludes environmental knowledge and awareness significantly and positively predicts sustainability performance and the first condition necessary for the mediation is satisfied.

Step 2 shows that $33.9 \%$ of the variation in employee green behaviour is explained by environmental knowledge and awareness. Remaining $66.1 \%$ of variation is explained by other factors which are not taken into consideration. Further, if environmental knowledge and awareness is increased by one unit, employee green behaviour will increase by 0.541 units. Thus, step two concludes environmental knowledge and awareness significantly and positively predicts employee green behaviour and second condition necessary for the mediation is satisfied.

Results of step 3 indicates that $47.1 \%$ of the variation in sustainability performance is explained by employee green behaviour. Remaining 52.9\% of variation is explained by other factors which are not taken into consideration. And also, when employee green behaviour is increased by one unit, sustainability performance will increase by 0.561 units. Thus, step three concludes employee green behaviour significantly and positively predicts sustainability performance and third condition necessary for the mediation is satisfied.

Step 4 indicates that $53.6 \%$ of the variation in sustainability performance is explained by environmental knowledge \& awareness and employee green behaviour. Remaining $46.4 \%$ of variation is explained by other factors which are not taken into consideration.

Further, when environmental knowledge and awareness is increased by one unit, sustainability performance will increase by 0.239 units. It also indicates that B coefficient for employee green behaviour is 0.412 , which means when employee green behaviour is increased by one unit, sustainability performance will increase by 0.412 units.

Finally, the results of this study show that since environmental knowledge $\&$ awareness is still significant when employee green behaviour is controlled but the strength of relationship has reduced from 0.461 to 0.239 , that the 
association between environmental knowledge and awareness and sustainability performance is partially mediated by employee green behaviour.

As there is a partial mediation, mediation effect or indirect effect is calculated as the product of path ' $a$ ' and ' $b$ ' coefficients as suggested by Sobel (1982).

$$
\text { Indirect Effect }=\mathrm{ax} \mathrm{b}=0.541 \times 0.412=0.222
$$

Total Effect $\left(\mathrm{c}_{1}\right)=$ Direct Effect $\left(\mathrm{c}^{\prime}{ }_{1}\right)+$ Indirect Effect $(\mathrm{ab})$

$$
0.461=0.239+0.222
$$

Indirect effect is 0.222 , which indicates on average 0.222 units of the overall difference of environmental knowledge and awareness on sustainability performance can be attributed to difference in employee green behaviour.

Statistical significance of the mediation has been tested with a test of statistical significance proposed by Sobel (1982). Values of regression coefficients have been applied to Sobel calculator and the results as follows,

$$
\begin{aligned}
\mathrm{Z} & =\frac{a b}{\sqrt{b^{2} S_{a}^{2}+a^{2} S_{b}^{2}}} \\
\mathrm{Z} & =\frac{0.222}{\sqrt{0.412^{2} \times 0.046_{a}^{2}+0.541^{2} \times 0.053_{b}^{2}}} \\
\mathrm{Z} & =6.485
\end{aligned}
$$

According to Mallinckrodt, Abraham, Wei, \& Russell (2006), since z-score (6.485) is greater than 1.96, the mediation is said to be statistically significant at $5 \%$ level of significance. That means employees green behaviour significantly carries the influence of environmental knowledge \& awareness on sustainability performance.

As per Sobel test since mediation is statistically significant, proportion of the effect that is mediated is calculated with the use following formula:

$$
\begin{aligned}
& \text { Proportion of mediation effect }=\frac{\mathrm{ab}}{\mathrm{c}} \times 100 \\
& =\frac{0.222}{0.461} \times 100 \\
& =48.16 \%
\end{aligned}
$$

Proportion of the partial mediation is $48.16 \%$ which indicates that $48.16 \%$ of total variation caused by environmental knowledge and awareness in sustainability performance is explained by employee green behaviour.

It can be concluded from the findings; the relationship between environmental knowledge and awareness and sustainability performance is partially mediated by employee green behaviour.

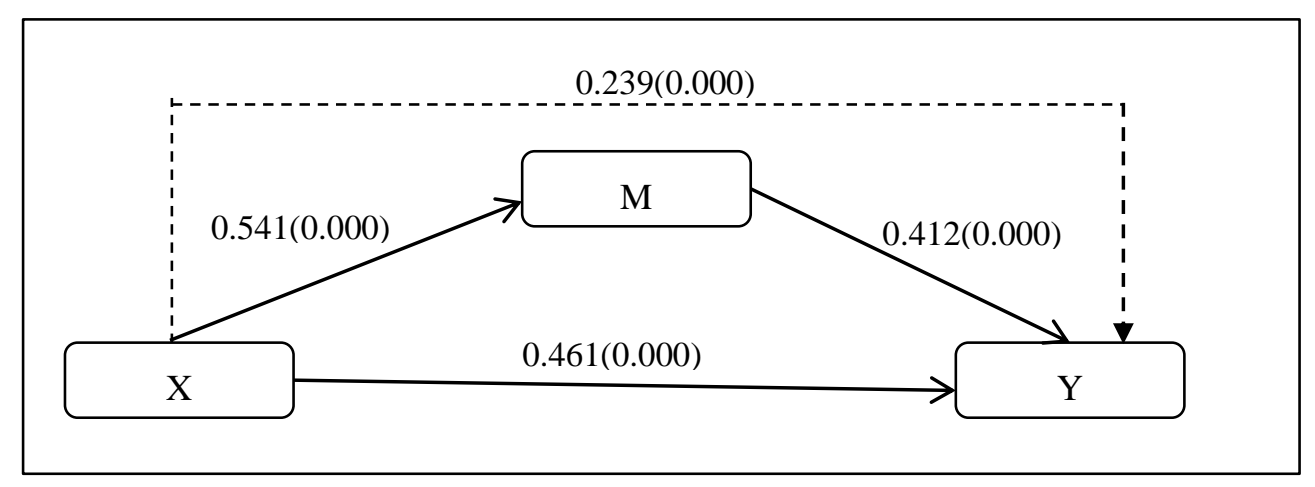

Figure 2. Results of Mediator Model 


\subsection{Discussion and Conclusion}

The results of $\mathrm{H}_{1}$ analysis indicates that there is a strong positive and significant relationship between environmental knowledge \& awareness and sustainability performance. Results obtained by the present study was validated by a number of previous researches. Holt and Barkemeyer (2012), who stated that there is a presumed link between environmental education, public awareness of the environment and sustainable development. Further, according to George \& Jayakumar (2017), the process of achieving long term environmental balance is signified by the green knowledge.

The results of $\mathrm{H}_{2}$ analysis suggests that that there is a strong positive and significant relationship between environmental knowledge \& awareness and employee green behaviour. Other studies also supported this finding. It has been suggested by the previous studies that environmental knowledge significantly predicts one's environmentally friendly behaviour of employees (Wang, Liu \& Qi, 2014; Opatha \& Kottawatta, 2020b). According to Chan et al. (2014), people's environmental awareness can improve their green behaviour.

Finding related to $\mathrm{H}_{3}$ shows that there is a strong positive and significant relationship between employee green behaviour and sustainability performance. Few studies support this finding. The empirical findings in literature demonstrate that employee behaviour significantly contributes to organizational environmental performance (Boiral, Talbot, \& Paillé, 2013; Malsha, Arulrajah, and Senthilnathan, 2020). Better environmental performance is often claimed to lead to better economic performance (Wagner, 2013). Green behaviour involvement can act as a stress buster. This will contribute to the firm's social performance (George \& Jayakumar, 2017).

The findings related to $\mathrm{H}_{4}$ verify the impact of environmental knowledge \& awareness on sustainability performance through employee green behaviour. Although there is no exact empirical evidence for this result, this study found that the relationship between environmental knowledge \& awareness and sustainability performance is partially mediated by employee green behaviour.

\section{Implications of the Study}

Findings of this study contribute to the sustainability performance literature in four important ways. First, as suggested by previous researchers, this study has examined sustainability performance as an outcome of employee green behaviour which has been neglected by the previous studies. As a result, the findings have contributed to close the empirical gap to some extent. Findings of this study contribute to the literature by interconnecting the employee behaviour and sustainability performance, which is relatively new (Ruepert et al., 2016) area of research. Hence, this study contributes to fill the knowledge gap to some degree. Furthermore, this study has been conducted in the banking sector in selected Divisional Secretariat Areas in Batticaloa District of Sri Lanka, hence this study contributes to fill the population gap to some extent.

The finding not only contributes to the studies related with sustainability performance and employees, but also provides banks with that may recognize green actions of the individuals as one of the parameters for choosing recruiting the personnel. To find the suitable individual, the human resources managers of the bank can ask about the environmentally friendly practices and perspectives obtained from other organizations during the interview process to learn more about their previous ecological actions.

\section{Recommendations of the Study}

Findings of the study suggests that an organization who wishes to improve their sustainability performance has to consider the critical role of employees and this study has offered possible recommendations to the banks to engage employees in sustainability performance.

One of the recommendations of this study is that the introduction and implementation of training programmes on a regular basis is needed to enhance the environmental knowledge and awareness of the employees and managers. Since workers may be unfamiliar with sustainability principles and practices, once it is decided by an organization to transform its ongoing processes to be more environmental friendly, employees can be subjected to a great deal of pressure. Employees must therefore, be properly prepared to deal with concepts and practices of sustainability.

Along with those training sessions, banks can develop ethical standards for green behaviour of employees, allowing them to promote and reward employees who exhibit green behaviours.

Third, conducting environmental awareness campaigns, which enable employees to recognize the value of sustainability performance and when designing awareness programmes and other initiatives, practitioners could benefit from targeting simple and enjoyable employee green behaviours.

Further, banks should consider environmental knowledge $\&$ awareness in future recruitments as well. Banks can 
consider environmental knowledge, awareness, green orientation and green qualifications of the candidates as criteria while selecting people for the vacancies.

\section{Limitations and Directions for the Future Research}

When interpreting the results many limitations should be considered. First, this study employed a cross-sectional design, which may prohibit to understand a perfect casual model. Even though, current study relies on literature logic and plausibility to reach a conclusion, future works with a longitudinal design might be successful in establishing perfect casual relationships.

Second, this study was conducted in one industry, selected commercial banks in selected areas of Batticaloa District in Sri Lanka. Given the unique characteristics of this context, it may not be appropriate to generalize the conclusions of the study to other industries or countries and future research may therefore examine similar research models in different contexts and industries are required.

Third, because this study was carried out at an individual level, it is recommended that further studies can be carried out at institutional and organizational levels.

Fourth, according to Ones and Dilchert (2012), achieving sustainability entails both doing the right thing as well as not doing the wrong thing. Therefore, it is critical importance to understand behaviours that detract from organizational sustainability performance. It would be necessary for studies in future to establish a metric of harmful behaviour centered on detrimental results.

Finally, even if the four conditions/steps of a mediational model were met in the study, alternative models that fit the data are likely. Because the predictor/independent, mediator and outcome/dependent variables were measured at the same point in time, the direction of the relationships among these variables were uncertain. For example, a reverse causal order might occur. Furthermore, the other variables which were not considered in this study may impact both the mediating and the outcome variables. Hence, future studies should consider some variables such as environmental attitude, green leadership and organizational environmental support etc.

\section{References}

Alhaddi, H. (2015). Triple bottom line and sustainability: A literature review. Business and Management Studies, l(2), 6-10. https://doi.org/10.11114/bms.v1i2.752

Andersson, L., \& Bateman, T. (2000). Individual environmental initiative: Championing natural environmental issues in U.S. business organizations. Academy of Management Journal, 43, 548-570. https://doi.org/10.5465/1556355

Anu Singh, L., \& Shikha, G. (2015). Impact of green human resource factors on environmental performance in manufacturing companies: An empirical evidence. International Journal of Engineering and Management Sciences, 6(1), 25-30.

Arboleda, A. M., \& Alonso, J. C. (2014). Design awareness and purchase intention: an item response theory approach. Academia Revista Latinoamericana de Administracion, 27(1), 138-155. https://doi.org/10.1108/ARLA-08-2013-0112

Arcury, T. A., \& Johnson, T. P. (1987). Public environmental knowledge: a statewide survey. The Journal of Environmental Education, 18(4), 31-37. https://doi.org/10.1080/00958964.1987.9942746

Baker, M., \& Schaltegger, S. (2015). Pragmatism and new directions in social and environmental accountability research. Accounting, Auditing and Accountability Journal, 28(2), 263-294. https://doi.org/10.1108/AAAJ-08-2012-01079

Baron, R. M., \& Kenny, D. A. (1986). The moderator-mediator variable distinction in social psychological research: Conceptual, strategic, and statistical considerations. Journal of Personality and Social Psychology, 51(6), 1173-1182. https://doi.org/10.1037/0022-3514.51.6.1173

Berrone, P., \& Gomez-Mejia, L. R. (2009). Environmental performance and executive compensation: An integrated agency-institutional perspective. Academy of Management Journal,52(1), 103-126. https://doi.org/10.5465/amj.2009.36461950

Bissing-Olson, M. J., Iyer, A., Fielding, K. S., \& Zacher, H. (2013). Relationships between daily affect and pro-environmental behaviour at work: the moderating role of pro-environmental attitude. Journal of Organizational Behaviour, 34(2), 156-175. https://doi.org/10.1002/job.1788

Boiral, O., Paillé, P., \& Raineri, N. (2015). The nature of employees' pro-environmental behaviours. The Psychology of Green Organizations, 12-32. 
https://doi.org/10.1093/ACPROF:OSO/9780199997480.003.0002

Boiral, O., Talbot, D., \& Paillé, P. (2013). Leading by Example: A Model of Organizational Citizenship Behaviour for the Environment. Business Strategy and the Environment, 24, 532-550. https://doi.org/10.1002/bse.1835

Bower, G. H. (1990). Awareness, the unconscious, and repression: an experimental psychologist's perspective.In Singer, J. L. (Ed.), Repression and Dissociation: Implications for Personality Theory, Psychopathology, and Health (pp. 209-231). Chicago, IL: The University of Chicago Press.

Burawat, P. (2019). The relationships among transformational leadership, sustainable leadership, lean manufacturing and sustainability performance in Thai SMEs manufacturing industry. International Journal of Quality \& Reliability Management, 36(6), 1014-1036. https://doi.org/10.1108/IJQRM-09-2017-0178

Chan, E. S. W, Hon, E. H. Y., Chan, W., \& Okumus, F. (2014). What drives employees' intentions to implement green practices in hotels? The role of knowledge, awareness, concern and ecological behaviour. International Journal of Hospitality Management, 40, 20-28. https://doi.org/10.1016/j.ijhm.2014.03.001

Davenport, T. H., \& Prusak, L. (1998). Working Knowledge: Managing what your Organization Know, Harvard Business School Press, Boston, MA.

Elkington, J. (1994). Towards the sustainable corporation: Win-win-win business strategies for sustainable development. California management review, 36(2), 90-100. https://doi.org/10.2307/41165746

Elkington, J. (1998). Accounting for the triple bottom line. Measuring Business Excellence, 2(3), 18-22. https://doi.org/10.1108/eb025539

Epstein, M. J., Yuthas, K., \& Buhovac, A. R. (2010). Implementing sustainability: the role of leadership and organisational culture. Strategic Finance, 41-47.

Fernandez, E., Junquera, B., \& Ordiz, M. (2003). Organizational culture and human resources in the environmental issue: A Review of the literatüre. International Journal of Human Resource Management, 14(4), 634-656. https://doi.org/10.1080/0958519032000057628

Gatersleben, B., Steg, L., \& Vlek, C. (2002). Measurement and determinants of environmentally significant consumer behaviour. Environment and Behaviour, 34(3), 335-362. https://doi.org/10.1177/0013916502034003004

George, J. S., \& Jayakumar, K. N. (2017). Is it time to promote employee green behaviour? The need and scope. Journal of Management Research and Analysis, 4(3), 117-122. https://doi.org/10.18231/2394-2770.2017.0017

Goel, P. (2010). Triple Bottom Line Reporting: An Analytical Approach for Corporate Sustainability. Journal of Finance Accounting and Management, 1(1), 27-42.

Gogtay, N. J., \& Thatte, U. M. (2017). Statistics for Researcher: Principles of Correlation Analysis. Journal of the Association of Physicians of India, 65, 78-80.

Holt, D., \& Barkemeyer, R. (2012). Media coverage of sustainable development issues - attention cycles or punctuated equilibrium? Sustainable Development 20, 1-17. https://doi.org/10.1002/sd.460

Iqbal, Q., Ahmad, N. H., \& Ahmad, B. (2019). Enhancing sustainable performance through job characteristics via workplace spirituality: A study on SMEs. Journal of Science and Technology Policy Management, https://doi.org/10.1108/JSTPM-02-2018-0022

Iqbal, Q., Hassan, S. H., Akhtar, S., \& Khan, S. (2018). Employee's green behavior for environmental sustainability: a case of banking sector in Pakistan. World Journal of Science, Technology and Sustainable Development, 15(2), 118-130. https://doi.org/10.1108/WJSTSD-08-2017-0025

Jabbour, C. J. C., \& de Sousa Jabbour, A. B. L. (2016). Green Human Resource Management and Green Supply Chain Management: linking two emerging agendas. Journal of Cleaner Production, 112, 1824-1833. https://doi.org/10.1016/j.jclepro.2015.01.052

Kaiser, F. G., Oerke, B., \& Bogner, F. X. (2007). Behaviour-based environmental attitude: Development of an instrument for adolescents. Journal of Environmental Psychology, 27(3), 242-251. https://doi.org/10.1016/j.jenvp.2007.06.004

Kaplan, S. (1991). Beyond rationality: clarity-based decision making. In Garling, T.,Evans, G. (Eds.), Environment, Cognition and Action (pp. 171-190). Oxford University Press, New York. 
http://doi.org/10.1093/oso/9780195062205.003.0014

Khan, E. A., \& Quaddus, M. (2015). Development \& validation of a scale for measuring sustainability factors of informal microenterprises-A qualitative and quantitative approach. Entrepreneurship Research Journal, 5(4), 347-372. https://doi.org/10.1515/erj-2014-0017

Kiernan, M. (2001). Eco-value, sustainability, and shareholder value: Driving environmental performance to the bottom line. Environmental Quality Management, 10(4), 1-12. https://doi.org/10.1002/tqem.1100

Kim, G. W., Vaswani, R. T., Kang, W., Nam, M., \& Lee, D. (2017). Enhancing Eco-literacy through Traditional Ecological Knowledge in Proverbs. Sustainability, 9, 1182-1194. https://doi.org/10.3390/su9071182

Kim, S. H., Kim, M., Han, H. S., \& Holland, S. (2016). The determinants of hospitality employees' pro-environmental behaviours: The moderating role of generational differences. International Journal of Hospitality Management, 52, 56-67. https://doi.org/10.1016/j.ijhm.2015.09.013

Kollmuss, A., \& Agyeman, J. (2002). Mind the gap: why do people act environmentally and what are the barriers to pro-environmental behaviour? Environmental Education Research, 8(3), 239-260. https://doi.org/10.1080/13504620220145401

Korzeb, Z., \& Samaniego-Medina, R. (2019). Sustainability Performance: A Comparative Analysis in the Polish Banking Sector. Sustainability, 11(3), 653-669. https://doi.org/10.3390/su11030653

Kwatra, S., Pandey, S., \& Sharma, S. (2014). Understanding public knowledge and awareness on e-waste in an urban setting in India: A case study for Delhi. Management of Environmental Quality, 25(6), 752-765. https://doi.org/10.1108/MEQ-12-2013-0139

Langwell, C., \& Heaton, D. (2016). Using human resource activities to implement sustainability in SMEs. Journal of Small Business and Enterprise Development, 23(3), 652-670. https://doi.org/10.1108/JSBED-07-2015-0096

Largo-Wight, E., Chen, W. W., Dodd, V., \& Weiler, R. (2011). Healthy workplaces: The effects of nature contact at work on employee stress and health. Public Health Reports, 126, 124-130. https://doi.org/10.1177/00333549111260S116

Laszlo, C., \& Zhexembayeva, N. (2011). Embedded Sustainability: The Next Big Competitive Advantage, UK Greenleaf Publishing, Sheffield.

Lo, S. H., Peters, G. J. Y., \& Kok, G. (2012). A review of determinants of and interventions for pro-environmental behaviours in organizations. Journal of Applied Social Psychology, 42(12), 2933-2967. https://doi.org/10.1111/j.1559-1816.2012.00969.x

Mallinckrodt, B., Abraham, W. T., Wei, M., \& Russell, D. W. (2006). Advances in testing the statistical significance of mediation effects. Journal of Counseling Psychology, 53(3), 372-378. https://doi.org/10.1037/0022-0167.53.3.372

Malsha, K. P. P. H. G. N., Arulrajah, A. A., \& Senthilnathan, S. (2020). Mediating role of employee green behaviour towards sustainability performance of banks. Journal of Governance \& Regulation, 9(2), 92-102. https://doi.org/10.22495/jgrv9i2art7

Masri, H. A., \& Jaaron, A. A. (2017). Assessing green human resources management practices in Palestinian manufacturing context: An empirical study. Journal of Cleaner Production, 143, 474-489. https://doi.org/10.1016/j.jclepro.2016.12.087

McKenzie, G., \& Wolfe, S. (2004). The impact of environmental risk on the UK banking sector. Applied Financial Economics, 14(14), 1005-1016. https://doi.org/10.1080/0960310042000261880

Mostafa, M. M. (2006). Antecedents of Egyptian consumers' green purchase intentions: A hierarchical multivariate regression model. Journal of International Consumer Marketing, 19(2), 97-126. https://doi.org/10.1300/J046v19n02_06

Narayanan, V., \& Boyce, G. (2019). Exploring the transformative potential of management control systems in organizational change towards sustainability. Accounting, Auditing \& Accountability Journal. https://doi.org/10.1108/AAAJ-04-2016-2536

Norton, T. A., Zacher, H., \& Ashkanasy, N. M. (2015). Pro-environmental organizational culture and climate. In J. L. Robertson \& J. Barling (Eds.), The psychology of green organizations (pp. 322-348). New York, NY: Oxford University Press. https://doi.org/10.1093/acprof:oso/9780199997480.003.0014 
O'Donohue, W., \& Torugsa, N. (2016). The moderating effect of 'Green' HRM on the association between proactive environmental management and financial performance in small firms. The International Journal of Human Resource Management, 27(2), 239-261. https://doi.org/10.1080/09585192.2015.1063078

Ones, D. S., \& Dilchert, S. (2012). Employee green behaviours. In S. E. Jackson, D. S. Ones \& S. Dilchert (Eds.), Managing HR for environmental sustainability (pp. 85-116). San Francisco, CA: Jossey-Bass/Wiley.

Opatha, H. H. D. N. P. (2015). Organizational Behaviour: The Human Side of Work. Colombo: Department of HRM, University of Sri Jayewardenepura.

Opatha, H. H. D. N. P. (2019). Sustainable Human Resource Management: Expanding Horizons of HRM, Colombo: Department of HRM, University of Sri Jayewardenepura.

Opatha, H. H. D. N. P., \& Arulrajah, A. A. (2014). Green human resource management: simplified general reflections. International Business Research, 7(8), 101-112. https://doi.org/10.5539/ibr.v7n8p101

Opatha, H. H. D. P. J., \& Kottawatta, H. (2020a). Green HRM and Environmental (Green) Attitude: Do Green HRM Practices of Sri Lankan Tiles Industry Affect to Determine the Environmental (Green) Attitudes of the Employees?. International Journal of Management Excellence, 15(2), 2207-2219.

Opatha, H. H. D. P. J., \& Kottawatta, H. (2020b). Impact of Green Attitude on Green Work Behavior: An Empirical Study of Employees in a Sri Lankan Tiles Manufacturing Company. Asian Journal of Social Science and Management Technology, 4(2), 1-7. https://doi.org/10.20448/journal.500.2020.72.114.123

Özçelik, F., \& Öztürk, B. A. (2014). Evaluation of banks' sustainability performance in Turkey with grey relational analysis. Muhasebe ve Finansman Dergisi, 63, 189-210. http://doi.org/10.25095/mufad.396484

Paille, P., Boiral, O., \& Chen, Y. (2013). Linking environmental management practices and organizational citizenship behaviour for the environment: a social exchange perspective. The International Journal of Human Resource Management, 24(18), 3552-3575. https://doi.org/10.1080/09585192.2013.777934

Palmberg, I., Berg, I., Jeronen, E., Kärkkäinen, S., Norrgård-Sillanpää, P., Persson, C., \& Yli-Panula, E. (2015). Nordic-Baltic student teachers' identification of and interest in plant and animal species: The importance of species identification and biodiversity for sustainable development. Journal of Science Teacher Education, 26(6), 549-571. https://doi.org/10.1007/s10972-015-9438-z

Robertson, J. L., \& Barling, J. (2013). Greening organizations through leaders' influence on employees' proenvironmental behaviours. Journal of Organizational Behaviour, 34(2), 176-194. https://doi.org/10.1002/job.1820

Roy, M. J., Boiral, O., \& Paillé, P. (2013). Pursuing quality and environmental performance: Initiatives and supporting processes. Business Process Management Journal, 19(1), 30-53. https://doi.org/10.1108/14637151311294859

Ruepert, A., Keizer, K., Steg, L., Maricchiolo, F., Carrus, G., Dumitru, A., \& Moza, D. (2016). Environmental considerations in the organizational context: A pathway to pro-environmental behaviour at work. Energy Research \& Social Science, 17, 59-70. https://doi.org/10.1016/j.erss.2016.04.004

Safari, A., Salehzadeh, R., Panahi, R., \& Abolghasemian, S. (2018). Multiple pathways linking environmental knowledge and awareness to employeese green behaviour. Corporate Governance: The International Journal of Business in Society, 18(1), 81-103. https://doi.org/10.1108/CG-08-2016-0168

Schaltegger, S., \& Wagner, M. (2006). Integrative management of sustainability performance, measurement and reporting. International Journal of Accounting, Auditing and Performance Evaluation, 3(1), 1-19. https://doi.org/10.1504/IJAAPE.2006.010098

Sinha, A., Pal, D. K., Kasar, P. K., Tiwari, R., \& Sharma, A. (2008). Knowledge, attitude and practice of disaster preparedness and mitigation among medical students. Disaster Prevention and Management: An International Journal, 17(4), 503-507. https://doi.org/10.1108/09653560810901746

Sobel, M. E. (1982). Asymptotic Confidence Intervals for Indirect Effects in Structural Equation Models. Sociological Methodology, 13, 290-321. https://doi.org/10.2307/270723

Teixeira, A. A., Jabbour, C. J. C., \& de Sousa Jabbour, A. B. L. (2012). Relationship between green management and environmental training in companies located in Brazil: A theoretical framework and case

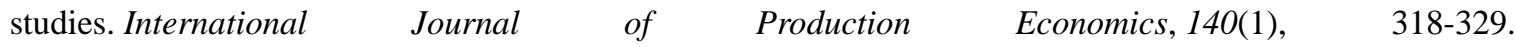
https://doi.org/10.1016/j.ijpe.2012.01.009 
Thevanes, N., \& Arulrajah, A. A. (2016). The Relationships among Environmental Training, Environmental Attitude of Employee, Environmental Behavior of Employee and Environmental Orientation of Organization: A Review of Literature. Proceedings of the $13^{\text {th }}$ International Research Conference on Business Management (ICBM), University of Sri Jayewardenepura, Sri Lanka.

Thevanes, N., \& Arulrajah, A. A. (2020). Environmental Training and Environmental Orientation of Organization: The Mediating Role of Environmental Behavior of Employee, Sri Lankan Journal of Human Resource Management, 10(2), 46-62.

Turan, F. K., Scala, N. M., Kamrani, A., \& Needy, K. L. (2008). Organizational sustainability: A new project portfolio management approach that integrates financial and non-financial performance measures. In IIE Annual Conference and Expo 2008 (pp. 1025-1030). University of Pittsburgh.

Valente, M. (2012). Theorizing Firm Adoption of Sustaincentrism. Organizational Studies, 33(4), 563-591. https://doi.org/10.1177/0170840612443455

Vinojini, M., \& Arulrajah, A. A. (2017), The Pro-Environmental Behaviour of Employee in an Apparel Manufacturing Organization in Nuwara-Eliya District of Sri Lanka, Sri Lankan Journal of Human Resource Management, 7(1), 1-17. http:/doi.org/10.44038/sljhrm.v7i1.5634

Wagner, M. (2013). Green' human resource benefits: Do they matter as determinants of environmental management system implementation? Journal of Business Ethics, 114(3), 443-456. https://doi.org/10.1007/s10551-012-1356-9

Walz, S. M., \& Niehoff, B. P. (2000). Organizational citizenship behaviors: Their relationship to organizational effectiveness. Journal of Hospitality and Tourism Research, 24, 301-319. https://doi.org/10.1177/109634800002400301

Wang, H., Choi, J., \& Li, J. (2008). Too little or too much? Untangling the relationship between corporate philanthropy and firm financial performance. Organization Science, 19(1), 143-159. https://doi.org/10.1287/orsc.1070.0271

Wang, P., Liu, Q., \& Qi, Y. (2014). Factors influencing sustainable consumption behaviours: a survey of the rural residents in China. Journal of Cleaner Production, 63, 152-165. https://doi.org/10.1016/j.jclepro.2013.05.007

Weerakoon, W. M. S. M. B., Sellar, T., \& Arulrajah, A. A. (2021). Employee Green Behaviour of Selected Hotels in Polonnaruwa Area of Sri Lanka, Sri Lankan Journal of Human Resource Management, 11(1), 36-52.

World Commission on Environment and Development (WCED). (1987). Special working session. Our Common Future, WCED, PA.

Ziadat, A. H. (2010). Major factors contributing to environmental awareness among people in a third world country/Jordan. Environment, Development and Sustainability, 12(1), 135-145. https://doi.org/10.1177/109634800002400301

Zsóka, Á., Szerényi, Z. M., Széchy, A., \& Kocsis, T. (2013). Greening due to environmental education? Environmental knowledge, attitudes, consumer behaviour and everyday pro-environmental activities of Hungarian high school and university students. Journal of Cleaner Production, 48, 126-138. https://doi.org/10.1016/j.jclepro.2012.11.030

\section{Copyrights}

Copyright for this article is retained by the author(s), with first publication rights granted to the journal.

This is an open-access article distributed under the terms and conditions of the Creative Commons Attribution license (http://creativecommons.org/licenses/by/4.0/). 